BEST EVIDENCE TOPIC REPORTS

\title{
Towards evidence based emergency medicine: best BETs from the Manchester Royal Infirmary
}

\author{
K Mackway-Jones
}

Emerg Med J 2004;21:75-81

Best evidence topic reports (BETs) summarise the evidence pertaining to particular clinical questions. They are not systematic reviews, but rather contain the best (highest level) evidence that can be practically obtained by busy practising clinicians. The search strategies used to find the best evidence are reported in detail in order to allow clinicians to update searches whenever necessary. The BETs published below were first reported at the Critical Appraisal Journal Club at the Manchester Royal Infirmary ${ }^{1}$ or placed on the BestBETs web site. Each BET has been constructed in the four stages that have been described elsewhere. ${ }^{2}$ The BETs shown here together with those published previously and those currently under construction can be seen at http://www. bestbets.org. ${ }^{3}$

Six BETs are included in this issue of the journal.

- Oxygen therapy for uncomplicated myocardial infarction

- Gastric lavage in paracetamol poisoning

- Oral corticosteroids in acute urticaria

- Ice, pins, or sugar to reduce paraphimosis

- Intravenous aminophylline or salbutamol in moderate to severe asthma

- Hypertonic or isotonic saline in hypotensive patients with severe head injury

K Mackway-Jones, Department of Emergency Medicine, Manchester Royal Infirmary, Oxford Road, Manchester M13 9WL, UK; kevin.mackwayjones@man.ac.uk

1 Carley SD, Mackway-Jones K, Jones A, et al. Moving towards evidence based emergency medicine: use of a structured critical appraisal journal club. J Accid Emerg Med 1998;15:220-2.

2 Mackway-Jones K, Carley SD, Morton RJ, et al. The best evidence topic report: a modified CAT for summarising the available evidence in emergency medicine. J Accid Emerg Med 1998;15:222-6.

3 Mackway-Jones K, Carley SD. bestbets. org: Odds on favourite for evidence in emergency medicine reaches the worldwide web. J Accid Emerg Med 2000;17:235-6.

\section{Oxygen in acute uncomplicated myocardial infarction}

\section{Report by Richard Body, Senior House Officer Checked by Kerstin Hogg, Clinical Research Fellow Abstract}

A short cut review was carried out to establish whether supplemental oxygen reduces mortality in patients with uncomplicated acute myocardial infarction. Altogether 290 papers were found using the reported search, of which one presented the best evidence to answer the clinical question. The author, date and country of publication, patient group studied, study type, relevant outcomes, results and study weaknesses of this best paper are tabulated. A clinical bottom line is stated.

\section{Clinical scenario}

A 60 year old man presents to the emergency department with acute severe crushing chest pain. ECG shows changes consistent with acute myocardial infarction. You prescribe aspirin, thrombolysis, nitroglycerin, $\beta$ blockers, and high flow oxygen. You know that oxygen therapy is traditionally held to be beneficial in this situation, but wonder if there is any evidence that it reduces mortality.

\section{Three part question}

In [patients with acute uncomplicated myocardial infarction] does [oxygen therapy] lead to [reduced mortality]?

\section{Search strategy}

Medline 1966-10/03 using the OVID interface. [exp myocardial infarction OR myocardial infarct\$.mp OR MI.mp OR heart attack.mp OR exp Coronary Thrombosis OR acute coronary syndrome.mp] AND [exp oxygen OR oxygen.mp OR O2.mp OR exp oxygen inhalation therapy] AND [exp Mortality OR exp Hospital Mortality OR mortality.mp OR exp Death OR death.mp] LIMIT to human AND English.

\section{Search outcome}

Altogether 290 papers were identified, only one of which was relevant to the question (table 1).

\section{Comment(s)}

The routine use of oxygen in myocardial infarction has been widely advocated for many years. However, the only study to investigate the efficacy of this approach was underpowered to show a difference in mortality.

\section{- CLINICAL BOTTOM LINE}

In patients with uncomplicated acute myocardial infarction there is no evidence that supplemental oxygen reduces mortality. However the there is no evidence of harm. Further research is required before changes in current practice should be recommended.

Rawles JM, Kenmure ACF. Controlled trial of oxygen in uncomplicated myocardial infarction. BMJ 1976;1:1121-3.

\section{Gastric lavage in paracetamol poisoning}

\section{Report by Stewart Teece, Clinical Research Fellow Checked by Kerstin Hogg, Clinical Research Fellow Abstract}

A short cut review was carried out to establish whether gastric lavage is better than activated charcoal in cases of poisoning with paracetamol. Altogether 63 papers were found using the reported search, of which four presented the best evidence to answer the clinical question. The author, date and country of publication, patient group studied, study type, relevant outcomes, results and study weaknesses of these best papers are tabulated. A clinical bottom line is stated. 
Table 1

\begin{tabular}{|c|c|c|c|c|c|}
\hline $\begin{array}{l}\text { Author, date } \\
\text { and country }\end{array}$ & Patient group & $\begin{array}{l}\text { Study type } \\
\text { (level of evidence) }\end{array}$ & Outcomes & Key results & Study weaknesses \\
\hline \multirow[t]{3}{*}{$\begin{array}{l}\text { Rawles JM and } \\
\text { Kenmure ACR, } \\
\text { 1976, UK }\end{array}$} & $\begin{array}{l}157 \text { patients with acute } \\
\text { uncomplicated myocardial } \\
\text { infarction }\end{array}$ & PRCT & $\begin{array}{l}\text { Incidence of } \\
\text { arrhythmias }\end{array}$ & $\begin{array}{l}\text { More sinus tachycardia in } \\
\text { oxygen group }(p<0.05) \text {; no } \\
\text { other significant differences }\end{array}$ & No power calculation \\
\hline & $\begin{array}{l}\text { Oxygen } v \text { compressed air via } \\
M C \text { mask at } 61 / \mathrm{min} \text { for } \\
24 \text { hours }\end{array}$ & & $\begin{array}{l}\text { Number of patients } \\
\text { given analgesics/number } \\
\text { of doses given } \\
\text { (diamorphine) }\end{array}$ & No significant difference & $\begin{array}{l}\text { No assessment of } \\
\text { pain scores }\end{array}$ \\
\hline & & & Mortality & $\begin{array}{l}9 \vee 3 \text { deaths } \\
\text { (not significant) }\end{array}$ & $\begin{array}{l}\text { Effect of implementing } \\
\text { intention to treat analysis not } \\
\text { discussed }\end{array}$ \\
\hline
\end{tabular}

\section{Clinical scenario}

A 26 year old woman attends the emergency department 40 minutes after having taken $80 \times 500 \mathrm{mg}$ paracetamol tablets. As the dose taken is high and within the past hour you wonder whether she would benefit from gastric lavage.

\section{Three part question}

In [paracetamol poisoning] is [gastric lavage better than activated charcoal or nothing] at [reducing hepatotoxicity]?

\section{Search strategy}

Medline 1966-10/03 using the OVID interface. [exp acetaminophen OR paracetamol.mp OR acetaminophen.mp] AND [exp poisoning OR poison\$.mp OR exp overdose OR overdos\$.mp] AND [exp gastric lavage OR gastric lavage.mp OR gastric decontamination.mp OR exp gastric emptying OR gastric emptying.mp OR exp irrigation OR washout.mp] LIMIT to human AND English.

\section{Search outcome}

Altogether 63 papers found of which 59 were irrelevant or of insufficient quality. Four of the remaining papers are shown in table 2, the fifth is a position statement mentioned in the comments section.

\section{Comment(s)}

The 1997 Joint Position Statement by the American Academy of Clinical Toxicology, European Association of Poisons Centres and Clinical Toxicologists stated gastric lavage should not be routinely used for poisoned patients. A similar statement from the British Poisons Centres indicates that gastric lavage is only to be used within 60 minutes of overdose and only with drugs not absorbed by charcoal.

\section{- CLINICAL BOTTOM LINE}

Gastric lavage is less effective than charcoal alone after paracetamol poisoning.

Underhill TJ, Greene MK, Dove AF. A comparison of the efficacy of gastric lavage, ipecacuanha and activated charcoal in the emergency management of paracetemol overdose. Arch Emerg Med 1990;7:148-54.

Buckley NA, Whyte IM, O'Connell DL, et al. Activated charcoal reduces the need for $\mathrm{N}$-acetylcysteine after acetaminophen (paracetemol) overdose. I Toxicol Clin Toxicol 1999;37:753-7

Grierson R, Green R, Sitar DS, et al. Gastric lavage for liquid poisons. Ann Emerg Med 2000;35:435-9.

Christophersen AB, Levin D, Hoegberg LCG, et al. Activated charcoal alone or after gastric lavage: a simulated large paracetamol intoxication. $\mathrm{Br} J \mathrm{Clin}$ Pharmacol 2002; 53:312-17.

Vale JA. Position statement: gastric lavage. American Academy of Clinical Toxicology; European Association of Poisons Centres and Clinical Toxicologists. J Toxicol Clin Toxicol 1997:35:711-19.

\section{Oral corticosteroids in acute urticaria}

\section{Report by M Poon, Paediatric Registrar Checked by C Reid, Registrar}

\section{Abstract}

A short cut review was carried out to establish whether the addition of oral corticosteroids to antihistamines leads to a

\section{Table 2}

\begin{tabular}{|c|c|c|c|c|c|}
\hline $\begin{array}{l}\text { Author, date } \\
\text { and country }\end{array}$ & Patient group & $\begin{array}{l}\text { Study type } \\
\text { (level of evidence) }\end{array}$ & Outcomes & Key results & Study weaknesses \\
\hline $\begin{array}{l}\text { Underhill TJ et al, } \\
\text { 1990, UK }\end{array}$ & $\begin{array}{l}60 \text { patients taken } 5 \mathrm{~g} \text { or } \\
\text { more within } 4 \text { hours of } \\
\text { attendance. Gastric lavage } \\
(14) v \text { ipecacuanha(21) } v \\
\text { activated charcoal(20) or } \\
\text { nothing(5) }\end{array}$ & $\mathrm{RCT}$ & $\begin{array}{l}\text { Plasma concentrations } \\
\text { at } 0,1.0,1.5 \text {. and } \\
2.5 \text { hours after } \\
\text { treatment }\end{array}$ & $\begin{array}{l}39.3 \% \text { reduction in } \\
\text { concentration } \\
\text { compared with } 52.2 \% \\
\text { charcoal }\end{array}$ & Small Study \\
\hline $\begin{array}{l}\text { Buckley NA et al, } \\
\text { 1999, Australia }\end{array}$ & $\begin{array}{l}981 \text { consecutive } \\
\text { paracetamol overdose. Gastric } \\
\text { lavage and charcoal } v \text { charcoal } \\
\text { alone } v \text { nothing }\end{array}$ & Observational study & $\begin{array}{l}\text { Patients developing } \\
\text { high risk concentrations }\end{array}$ & $\begin{array}{l}\text { No statistically } \\
\text { significant improvement } \\
\text { with lavage + charcoal } \\
\text { than charcoal alone. }\end{array}$ & \\
\hline $\begin{array}{l}\text { Grierson R et al } \\
2000, \text { Canada }\end{array}$ & $\begin{array}{l}10 \text { volunteers given } 4.0 \mathrm{~g} \\
\text { paracetamol. Gastric lavage at } \\
1 \text { hour compared with no } \\
\text { treatment as crossover. }\end{array}$ & Crossover study & $\begin{array}{l}8 \text { plasma } \\
\text { concentrations over } \\
8 \text { hours }\end{array}$ & $\begin{array}{l}\text { Reduction of } 20 \% \\
(95 \% \mathrm{Cl} 3 \% \text { to } 37 \% \text { ) }\end{array}$ & $\begin{array}{l}\text { Small study. Low } \\
\text { dose. Liquid } \\
\text { paracetamol only }\end{array}$ \\
\hline $\begin{array}{l}\text { Christophersen AB et al, } \\
\text { 2002, Denmark }\end{array}$ & $\begin{array}{l}12 \text { volunteers given } \\
50 \mathrm{mg} / \mathrm{kg} \text { paracetamol. } \\
\text { Lavage + charcoal } v \text { charcoal }\end{array}$ & Crossover study & $\begin{array}{l}12 \text { plasma } \\
\text { concentrations over } \\
7 \text { hours }\end{array}$ & $\begin{array}{l}\text { Charcoal } 66 \% \\
\text { reduction in } \\
\text { concentration, } \\
\text { lavage + charcoal } \\
48.2 \%\end{array}$ & $\begin{array}{l}\text { Small numbers Low } \\
\text { dose }\end{array}$ \\
\hline
\end{tabular}


more rapid resolution of urticaria. Thirty nine papers were found using the reported search, of which two presented the best evidence to answer the clinical question. The author, date and country of publication, patient group studied, study type, relevant outcomes, results and study weaknesses of these best papers are tabulated. A clinical bottom line is stated.

\section{Clinical scenario}

A 4 year old girl presents to the emergency department with an urticarial rash. Her general practitioner has prescribed an oral antihistamine but the rash has persisted. You wonder if there is a role for oral corticosteroids in this otherwise well child.

\section{Three part question}

In a [child with acute urticaria] does the [addition of oral corticosteroids to antihistamines] lead to [more rapid resolution of symptoms].

\section{Search strategy}

Cochrane Database of Systematic Reviews Issue 3, 2003. Medline 1966-10/03 using the OVID interface. Cochrane: 'urticaria' Medline: [exp urticaria OR urticaria\$.mp] AND [exp steroids OR steroid\$.mp OR exp adrenal cortex hormones OR corticosteroid\$.mp] AND [Randomized Controlled Trial.pt OR Controlled Clinical Trial.pt] LIMIT to human.

\section{Search outcome}

Cochrane Database of Sytematic Reviews-no relevant results. Medline search results-39 articles, of which two were relevant (table 3 ).

\section{Comment(s)}

There are no studies specifically aimed at children with acute urticaria. These limited trials demonstrate improvement in symptoms when prednisolone is prescribed, but larger studies are needed.

\section{- CLINICAL BOTTOM LINE}

In patients presenting to the emergency department with acute uricaria, the addition of oral prednisolone to an antihistamine results in decreased itch and more rapid rash resolution.

Pollack CV Jr, Romano TJ. Outpatient management of acute urticaria: the role of prednisone. Ann Emerg Med 1995;26:547-5.

Zuberbier T, Ifflander J, Semmler C, et al. Acute urticaria: clinical aspects and therapeutic responsiveness. Acta Derm Venereol 1996;76:295-7.

\section{Ice, pins, or sugar to reduce paraphimosis}

\section{Report by Kevin Mackway-Jones, Consultant Checked by Stewart Teece, Clinical Research Fellow} Abstract

A short cut review was carried out to establish which of the ice glove technique, the multiple puncture technique, or the application of sugar was the best approach for paraphimosis reduction. Thirty three papers were found using the reported search, of which three presented the best evidence to answer the clinical question. The author, date and country of publication, patient group studied, study type, relevant outcomes, results and study weaknesses of these best papers are tabulated. A clinical bottom line is stated.

\section{Clinical scenario}

You are asked to see a 19 year old man who has presented to the emergency department with paraphymosis. He states that he fell asleep after sex the night before and woke up with swelling. Simple traction has failed to cure the problem (but has brought tears to his eyes). A surgeon, a specialist registrar in emergency medicine, and a urologist are already in attendance. The first says that multiple punctures should be made with a needle, the second that an iced glove should be used, and the third that sugar should be applied. You wonder whether any of the suggested methods are evidence based.

\section{Table 3}

\begin{tabular}{|c|c|c|c|c|c|}
\hline $\begin{array}{l}\text { Author, date and } \\
\text { country }\end{array}$ & Patient group & $\begin{array}{l}\text { Study type } \\
\text { (level of evidence) }\end{array}$ & Outcomes & Key results & Study weaknesses \\
\hline \multirow[t]{2}{*}{$\begin{array}{l}\text { Pollack CV Jr and } \\
\text { Romano TJ, 1995, } \\
\text { USA }\end{array}$} & $\begin{array}{l}43 \text { adult outpatients } \\
\text { with acute urticaria } \\
\text { given IM } \\
\text { diphenhydramine then } \\
\text { randomised to oral } \\
\text { hydroxyzine plus either } \\
20 \text { mg prednisone } 12 \\
\text { hourly for four days or } \\
\text { placebo }\end{array}$ & RCT & $\begin{array}{l}10 \text { point visual analogue } \\
\text { itch score at } 48 \text { hours. Itch } \\
\text { score at } 5 \text { days }\end{array}$ & $\begin{array}{l}\text { Mean } 48 \text { hour itch } \\
\text { score } 1.3 \text { in prednisone } \\
\text { group } v 4.4 \text { in control group. } \\
\text { Five day itch score } 0 \text { in } \\
\text { prednisone group } v 1.6 \text { in } \\
\text { control group }\end{array}$ & Adult patients only \\
\hline & & & $\begin{array}{l}\text { Description of rash } \\
\text { at } 48 \text { hours and } 5 \text { days }\end{array}$ & $\begin{array}{l}\text { No difference between } \\
\text { groups at } 48 \text { hours. } \\
\text { Rash resolved completely } \\
\text { at } 5 \text { days in prednisone } \\
\text { group }\end{array}$ & $\begin{array}{l}\text { Small study } \\
\text { No power calculation } \\
\text { Rash not described at five } \\
\text { days in control group }\end{array}$ \\
\hline $\begin{array}{l}\text { Zuberbier T et al, } \\
\text { 1996, Germany }\end{array}$ & $\begin{array}{l}109 \text { adult and } \\
\text { paediatric patients } \\
\text { with acute urticaria } \\
\text { treated with loratidine } \\
10 \mathrm{mg} \text { daily or } \\
\text { prednisolone } 50 \mathrm{mg} \\
\text { daily for three days } \\
\text { followed by loratidine } \\
10 \text { mg daily until } \\
\text { remission of symptoms }\end{array}$ & $\begin{array}{l}\text { Non-randomised } \\
\text { prospective } \\
\text { cohort study }\end{array}$ & $\begin{array}{l}\text { Days until cessation of } \\
\text { whealing }\end{array}$ & $\begin{array}{l}65.9 \% \text { of had cessation } \\
\text { of whealing by } 3 \text { days } \\
\text { and a further } 15.9 \% \text { by } \\
7 \text { days in Loratidine group, } \\
\text { compared with } 93.8 \% \text { by } \\
3 \text { days and a further } 3.1 \% \\
\text { by } 7 \text { days in the prednisolone } \\
\text { group. Resolution in all patients } \\
\text { after }>21 \text { days. NNT with } \\
\text { prednisolone for resolution of } \\
\text { symptoms by } 3 \text { days }=4\end{array}$ & $\begin{array}{l}\text { Number of children unstated } \\
\text { Different exclusion criteria } \\
\text { between groups (potentially } \\
\text { pregnant women excluded } \\
\text { from loratidine group) } \\
\text { s }\end{array}$ \\
\hline
\end{tabular}




\section{Three part question}

In [an adult male with irreducible paraphimosis] is [ice better than multiple puncturing or sugar] at [reducing swelling and allowing reduction]?

\section{Search strategy}

Medline 1966-10/03 using the OVID interface. [paraphymosis. mp OR paraphimosis.mp OR exp paraphimosis OR (foreskin. mp AND retraction.mp)] AND [reduc\$.mp OR exp ice OR ice\$.mp OR puncture\$.mp OR exp punctures OR sugar.mp].

\section{Search outcome}

Altogether 33 papers found, of which three were relevant (table 4).

\section{Comment(s)}

There are no comparative or randomised trials in this area. Current treatment is based wholly on custom, practice, and word of mouth. Further research is warranted.

\section{- CLINICAL BOTTOM LINE}

All three methods have been shown to work, but there is no evidence to show which is best. Local guidelines should be followed.

Houghton GR. The "iced-glove" method of treatment of paraphimosis. B J Surg 1973:60:876-7.

Gonzalez Fernandez M, Sousa Escandon MA, Parra Muntaner L. Sugar: treatment of choice in irreducible paraphimosis. Actas Urol Esp 2001 ;25:393-5.

Kumar V, Javle P. Modified puncture technique for reduction of paraphymosis. Ann R Coll Surg 2001;83:126-7.

\section{Is intravenous aminophylline better than intravenous salbutamol in the treatment of moderate to severe asthma?}

\section{Report by Andrew Munro, Registrar Checked by Michelle Jacobs, Specialist Registrar \\ Abstract}

A short cut review was carried out to establish whether intravenous salbutamol or intravenous aminophylline offers the quickest and least complicated treatment for patients with moderate to severe asthma not responding to inhaled therapy. Altogether 71 papers were found using the reported search, of which nine presented the best evidence to answer the clinical question. The author, date and country of publication, patient group studied, study type, relevant outcomes, results and study weaknesses of these best papers are tabulated. A clinical bottom line is stated.

\section{Clinical scenario}

A 20 year old man is brought to the emergency department in acute respiratory distress with asthma. He has a history of poor compliance with unstable asthma and several hospital admissions in the past. His old notes are available and you notice whenever intravenous treatment has been started he has been given aminophylline. You feel that the best drug is a $\beta_{2}$ agonist and that if it is not getting to the receptors via the airways then intravenous is the next best route. There is some dismay among the nursing staff when you formulate an intravenous regimen. They say they have never given it before. You wonder whether your approach is evidence based.

\section{Three part question}

In [patients with moderate to severe asthma resistant to inhaled $\beta_{2}$ agonists] does [IV aminophylline or IV salbutamol] result in [quicker relief with less side effects]?

\section{Search strategy}

Medline 1966-10/03 using the OVID interface. [(exp albuterol/OR salbutamol.mp) AND intravenous.mp] AND [exp asthma/OR exp bronchial spasm/OR exp bronchoconstriction/ OR bronchoconstriction.mp] AND [exp aminophylline/OR aminophylline.mp OR exp theophylline/OR theophylline.mp] LIMIT to human AND English.

\section{Search outcome}

Altogether 71 papers found of which 62 were considered irrelevant or of insufficient quality for inclusion. The remaining nine papers are shown in table 5.

\section{Comment(s)}

Multiple small trials of reasonable quality show intravenous salbutamol to be as good if not better at reversing obstructive airflow in asthmatic patients. Those studies that were equivocal used drug regimens that could be considered subtherapeutic or confounded. Side effects, although present seem to be well tolerated. Recent or high powered trials comparing the two drugs do not exist.

\section{- CLINICAL BOTTOM LINE}

Intravenous salbutamol should be considered a first line agent in the acute management of severe asthma in adults.

Beswick K, Davies J, Davey AJ. A comparison of intravenous aminophylline and salbutamol in the treatment of severe bronchospasm. Practitioner 1975;214:5616 .

Williams SJ, Parrish RW, Seaton A. Comparison of intravenous aminophylline and salbutamol in severe asthma. BMJ 1975:4:685.

Tribe AE, Wong RM, Robinson JS. A controlled trial of intravenous salbutamol and aminophylline in acute asthma. Med J Aust 1976;2:749-52.

Femi-Pearse D, George WO, llechukwu ST, et al. Comparison of intravenous aminophylline and salbutamol in severe asthma. BMJ 1977;1:491.

Johnson AJ, Spiro SG, Pidgeon J, et al. Intravenous infusion of salbutamol in severe acute asthma. BMJ 1978;1:1013-15.

Evans WV, Monie RD, Crimmins J, et al. Aminophylline, salbutamol and combined intravenous infusions in acute severe asthma. Br J Dis Chest 1980;74:385-9.

\begin{tabular}{|c|c|c|c|c|c|}
\hline $\begin{array}{l}\text { Author, date and } \\
\text { country }\end{array}$ & Patient group & $\begin{array}{l}\text { Study type } \\
\text { (level of evidence) }\end{array}$ & Outcomes & Key results & Study weaknesses \\
\hline $\begin{array}{l}\text { Houghton GR, } \\
1973 \text {, UK }\end{array}$ & $\begin{array}{l}10 \text { patients with paraphimosis } \\
\text { aged 8-91 years. } \\
\text { lced glove placed for five minutes }\end{array}$ & Case series & Reduction & 9 of 10 & $\begin{array}{l}\text { Small numbers } \\
\text { No controls }\end{array}$ \\
\hline $\begin{array}{l}\text { Gonzalez FM et al, } \\
2001 \text {, Spain }\end{array}$ & $\begin{array}{l}\text { Three patients with paraphimosis } \\
\text { Application of granulated sugar } \\
\text { for one to two hours }\end{array}$ & Case series & Reduction & All reduced & $\begin{array}{l}\text { Small numbers } \\
\text { No controls }\end{array}$ \\
\hline $\begin{array}{l}\text { Kumar V and } \\
\text { Javle P, 2001, UK } \\
\text { and India }\end{array}$ & $\begin{array}{l}45 \text { patients with paraphimosis } \\
\text { Multiple puncture in patients } \\
\text { with glans engorgement (39) }\end{array}$ & Case series & Reduction & $\begin{array}{l}\text { All reduced } \\
\text { if no skin changes }\end{array}$ & $\begin{array}{l}\text { Small numbers } \\
\text { No controls }\end{array}$ \\
\hline
\end{tabular}




\begin{tabular}{|c|c|c|c|c|c|}
\hline $\begin{array}{l}\text { Author, date } \\
\text { and country }\end{array}$ & Patient group & Study type (level of evidence) & Outcomes & Key results & Study weaknesses \\
\hline \multirow[t]{2}{*}{$\begin{array}{l}\text { Beswick K } \\
\text { et al, 1975, } \\
\text { UK }\end{array}$} & $\begin{array}{l}20 \text { patients in GP } \\
\text { setting with acute } \\
\text { bronchospasm }\end{array}$ & $\begin{array}{l}\text { Single blinded randomised } \\
\text { trial of IV salbutamol or } \\
\text { aminophylline }\end{array}$ & $\begin{array}{l}\text { Vital signs } \\
\text { PEFR FEV } 1 \text { FVC }\end{array}$ & $\begin{array}{l}\text { Same } \\
\text { Difference favouring } \\
\text { salbutamol at } 10 \text { and } \\
20 \text { min but not significant }\end{array}$ & $\begin{array}{l}\text { Small non-ED study } \\
\text { (most treated at home) }\end{array}$ \\
\hline & & & Side effects & $\begin{array}{l}\text { Significantly worse } \\
\text { profile for aminophylline }\end{array}$ & \\
\hline \multirow[t]{3}{*}{$\begin{array}{l}\text { Williams SJ } \\
\text { et al, 1975, } \\
\text { Wales }\end{array}$} & $\begin{array}{l}20 \text { acute asthmatic } \\
\text { patients with peak flow } \\
<25 \% \text { predicted, } \\
\mathrm{PaO}_{2}<68 \mathrm{~mm} \mathrm{Hg}\end{array}$ & $\begin{array}{l}\text { DBRCT One hour } \\
\text { infusion of either } 500 \mu \mathrm{g} \\
\text { aminophylline or } 500 \mathrm{~g} \\
\text { salbutamol }\end{array}$ & $\begin{array}{l}\text { Peak flow } \\
\text { Pulse }\end{array}$ & $\begin{array}{l}\text { Increased but not } \\
\text { significant for salbutamol } \\
\text { More tachycardia } \\
\text { (significant) with } \\
\text { salbutamol }\end{array}$ & Small numbers \\
\hline & & & BP & Fall in diastole & \\
\hline & & & Side effects & $\begin{array}{l}\text { Less tremor, nausea, no } \\
\text { difference in plasma }[\mathrm{K}+]\end{array}$ & \\
\hline \multirow[t]{2}{*}{$\begin{array}{l}\text { Tribe AE } \\
\text { et al, } 1976 \text {, } \\
\text { Australia }\end{array}$} & $\begin{array}{l}23 \text { acute asthma } \\
\text { patients }\end{array}$ & $\begin{array}{l}\text { DBRCT of IV } \\
\text { aminophylline } v \text { salbutamol }\end{array}$ & Spirometry & $\begin{array}{l}\text { Non-significant benefit } \\
\text { and peak effect of } \\
\text { aminophylline }\end{array}$ & $\begin{array}{l}\text { Suboptimal dose of } \\
\text { salbutamol }\end{array}$ \\
\hline & & & $A B G$ & $\begin{array}{l}\text { Quicker improvement in } \\
\text { oxygen tension with } \\
\text { salbutamol }\end{array}$ & Variable pre-trial treatment \\
\hline $\begin{array}{l}\text { Femi-Pearse D } \\
\text { et al, 1977, } \\
\text { Nigeria }\end{array}$ & $\begin{array}{l}50 \text { patients with peak } \\
\text { flow }<1651 / \mathrm{min}\end{array}$ & $\begin{array}{l}\text { Single and double blinded } \\
\text { trials of salbutamol and } \\
\text { aminophylline }\end{array}$ & $\begin{array}{l}\text { Five minutely } \\
\text { pulse and peak } \\
\text { flow measures }\end{array}$ & $\begin{array}{l}\text { Significant benefit in peak } \\
\text { flow at } 5 \mathrm{~min}(p<0.005) \\
\text { and } 20 \mathrm{~min}(p<0.05) \text { for } \\
\text { single blinded trial only for } \\
\text { salbutamol. No difference } \\
\text { in pulse rate }\end{array}$ & $\begin{array}{l}\text { Small trial } \\
\text { Low dose of salbutamol }\end{array}$ \\
\hline \multirow[t]{4}{*}{$\begin{array}{l}\text { Johnson AJ } \\
\text { et al, 1978, } \\
\text { UK }\end{array}$} & $\begin{array}{l}39 \text { of } 62 \text { acute asthmatic } \\
\text { patients unresponsive to } \\
\text { initial IV } 10 \text { min } \\
\text { aminophylline infusion } \\
\text { and nebulised salbutamol }\end{array}$ & $\begin{array}{l}\text { Single blinded RCT Either } \\
1 \mathrm{mg} / \mathrm{min} \text { aminophylline or } \\
10 \mu \mathrm{g} / \mathrm{min} \text { salbutamol }\end{array}$ & $\begin{array}{l}\text { Peak expiratory } \\
\text { flow } \\
\text { FEV1 }\end{array}$ & $\begin{array}{l}\text { Non-significant benefit } \\
\text { of aminophylline } \\
\text { Non-significant } \\
\text { benefit of salbutamol }\end{array}$ & $\begin{array}{l}\text { All received IV } \\
\text { aminophylline initially } \\
\text { No initial bolus of } \\
\text { salbutamol }\end{array}$ \\
\hline & & & FVC & $\begin{array}{l}\text { Non-significant benefit } \\
\text { of aminophylline }\end{array}$ & $\begin{array}{l}\text { Variable used of nebulised } \\
\text { salbutamol acutely }\end{array}$ \\
\hline & & & $\begin{array}{l}\text { Arterial gas } \\
\text { measurements }\end{array}$ & No difference & Not blinded to physicians \\
\hline & & & Pulse and BP & $\begin{array}{l}\text { Significant tachycardia } \\
\text { in salbutamol group }\end{array}$ & $\begin{array}{l}\text { Variable background } \\
\text { preventive treatment }\end{array}$ \\
\hline $\begin{array}{l}\text { Evans WV } \\
\text { et al, 1980, } \\
\text { UK }\end{array}$ & 21 acute asthma patients & $\begin{array}{l}\text { Single blinded RCT } \\
\text { comparing aminophylline, } \\
\text { salbutamol or combined IV }\end{array}$ & Spirometry & $\begin{array}{l}\text { Non-significantly quicker } \\
\text { time to improvement with } \\
\text { aminophylline and } \\
\text { combined infusion }\end{array}$ & $\begin{array}{l}\text { Small numbers } \\
\text { Variable baseline severity } \\
\text { Sub-therapeutic salbutamol } \\
\text { dosing }\end{array}$ \\
\hline \multirow[t]{2}{*}{$\begin{array}{l}\text { Sahay JN } \\
\text { et al, 1984, } \\
\text { UK }\end{array}$} & $\begin{array}{l}20 \text { adults with } \\
\mathrm{FEV}_{1}<70 \% \text { predicted }\end{array}$ & $\begin{array}{l}\text { Double blinded RCT } \\
\text { crossover of aminophylline, } \\
\text { terbutaline and salbutamol }\end{array}$ & Spirometry & $\begin{array}{l}\text { All produced significant } \\
\text { improvement, salbutamol } \\
\text { significantly better than } \\
\text { aminophylline to } 30 \mathrm{~min} \\
\text { after dose then no difference } \\
\text { with better peak effect. }\end{array}$ & $\begin{array}{l}\text { Small group, not acutely } \\
\text { unwell }\end{array}$ \\
\hline & & & $\begin{array}{l}\text { Vital signs and } \\
\text { side effects }\end{array}$ & $\begin{array}{l}\text { Salbutamol significantly } \\
\text { more tachycardia and } \\
\text { palpitations which return to } \\
\text { no difference at } 90 \mathrm{~min}\end{array}$ & \\
\hline \multirow[t]{2}{*}{$\begin{array}{l}\text { Sharma TN } \\
\text { et al, 1984, } \\
\text { India }\end{array}$} & $\begin{array}{l}30 \text { known asthmatic } \\
\text { patients with acute } \\
\text { bronchospasm }\end{array}$ & $\begin{array}{l}\text { RCT of aminophylline, } \\
\text { salbutamol or terbutaline }\end{array}$ & Spirometry & $\begin{array}{l}\text { Salbutamol significantly } \\
\text { better } \mathrm{FEV}_{1}\end{array}$ & Blinding not clear \\
\hline & & & Side effects & $\begin{array}{l}\text { Significantly more } \\
\text { palpitations with } \\
\text { salbutamol }\end{array}$ & $\begin{array}{l}\text { Salbutamol } 250 \mu \mathrm{g} \\
\text { given as } 1 \mathrm{~min} \text { bolus }\end{array}$ \\
\hline \multirow[t]{5}{*}{$\begin{array}{l}\text { Grief J } \\
\text { et al, 1985, } \\
\text { Israel }\end{array}$} & $\begin{array}{l}21 \text { patients (mean } \\
\text { age } 38 \text { years) with acute } \\
\text { or chronic asthma }\end{array}$ & $\begin{array}{l}\text { Single blinded crossover } \\
20 \text { min infusion of } \\
\text { salbutamol or } \\
\text { aminophylline }\end{array}$ & $\begin{array}{l}\% \text { Increase in } \\
\text { peak flow }\end{array}$ & $\begin{array}{l}\text { Salbutamol shows } \\
\text { significant benefit to } 30 \mathrm{~min} \\
(p<0.01) \text { and } 45 \mathrm{~min} \\
(p<0.05) \text { after infusion }\end{array}$ & Small study \\
\hline & & & Pulse rate & Tachycardia with salbutamol & \\
\hline & & & BP & No difference & Not fully blinded \\
\hline & & & Plasma $[K+]$ & Average drop of $0.6 \mathrm{mmol} / \mathrm{I}$ & \\
\hline & & & Tremor & More in salbutamol group & \\
\hline
\end{tabular}




\begin{tabular}{|c|c|c|c|c|c|}
\hline $\begin{array}{l}\text { Author, date } \\
\text { and country }\end{array}$ & Patient group & $\begin{array}{l}\text { Study type } \\
\text { (level of evidence) }\end{array}$ & Key results & Outcomes & Study weaknesses \\
\hline \multirow[t]{2}{*}{$\begin{array}{l}\text { Wade CE } \\
\text { et al, 1997, } \\
\text { Sweden }\end{array}$} & $\begin{array}{l}223 \text { patients with severe } \\
\text { head injuries and } \\
\text { hypotension. } 250 \mathrm{ml} 7.5 \% \\
\text { NaCl/ } 6 \% \text { Dextran } 70 \\
\text { (single bolus) } v \text { standard care } \\
\text { (usually Ringer's lactate) }\end{array}$ & $\begin{array}{l}\text { Cohort analysis } \\
\text { from six previous } \\
\text { PRCTs }\end{array}$ & 24 hour survival & $\begin{array}{l}\text { Odds ratio of } 1.92 \\
(p=0.06 \text { ) for survival } \\
24 \text { hours with HS }\end{array}$ & $\begin{array}{l}\text { Heterogeneous trials, } \\
\text { which were not all } \\
\text { designed to assess } \\
\text { head injured patients }\end{array}$ \\
\hline & & & Discharge Survival & $\begin{array}{l}\text { Odds ratio of } 2.12 \\
(p=0.048) \text { for survival } \\
\text { until discharge with HS }\end{array}$ & $\begin{array}{l}\text { Long term outcome } \\
\text { not assessed }\end{array}$ \\
\hline \multirow[t]{3}{*}{$\begin{array}{l}\text { Shackford SR } \\
\text { et al, 1998, } \\
\text { USA }\end{array}$} & $\begin{array}{l}34 \text { patients with severe head } \\
\text { injuries and undergoing ICP } \\
\text { monitoring. } 1.6 \% \mathrm{NaCl}(\mathrm{HS}) \mathrm{v} \\
\text { Ringer's lactate (RL) to treat } \\
\text { "episodes of haemodynamic } \\
\text { instability" during initial } \\
\text { resuscitation and for } 5 \text { days }\end{array}$ & PRCT & $\mathrm{ICP}$ & $\begin{array}{l}\text { No significant difference } \\
\text { between groups. } \\
\text { Maximum ICP fell } 9.1 \mathrm{~mm} \\
\mathrm{Hg} \text { with HS and rose } \\
2.5 \mathrm{~mm} \mathrm{Hg} \text { with RL } \\
(p<0.05)\end{array}$ & CPP not addressed \\
\hline & & & $\begin{array}{l}\text { Number of interventions } \\
\text { to control increased ICP }\end{array}$ & $\begin{array}{l}\text { Average of } 31 \\
\text { interventions per patient } \\
\text { with } H S v 11 \text { interventions } \\
\text { with } R L(p<0.01)\end{array}$ & $\begin{array}{l}\text { HS group had more } \\
\text { severe injuries }\end{array}$ \\
\hline & & & $\begin{array}{l}\text { Glasgow Outcome } \\
\text { Score at discharge }\end{array}$ & No significant difference & $\begin{array}{l}\text { Small numbers: a power } \\
\text { study indicated the need } \\
\text { for } 320 \text { patients but only } \\
34 \text { were enrolled }\end{array}$ \\
\hline \multirow[t]{7}{*}{$\begin{array}{l}\text { Simma B } \\
\text { et al, 1998, } \\
\text { Switzerland }\end{array}$} & $\begin{array}{l}32 \text { children with severe head } \\
\text { injury and ICP monitoring. } \\
1.6 \% \mathrm{NaCl}(\mathrm{HS} \text { ) v Ringer's } \\
\text { lactate (RL) as only IV fluid for } \\
3 \text { days following injury. }\end{array}$ & PRCT & $\begin{array}{l}\text { ICP and CPP } \\
\text { Number of interventions to } \\
\text { control increased ICP }\end{array}$ & $\begin{array}{l}\text { No significant difference } \\
\text { Average of } 44 \\
\text { interventions per patient } \\
\text { with } H S \text { v } 62 \text { per patient } \\
\text { with } R L \text {. }(p<0.02)\end{array}$ & $\begin{array}{l}\text { Small numbers: the power } \\
\text { calculation was directed } \\
\text { towards detecting a } \\
\text { difference in ICP }\end{array}$ \\
\hline & & & $\mathrm{Na}$ concentration and ICP & $\begin{array}{l}\text { Inverse correlation }(p<0.3) \\
\text { in both groups }\end{array}$ & \\
\hline & & & $\mathrm{Na}$ concentration and CPP & $\begin{array}{l}\text { Inverse correlation } \\
\text { significant only in HS group } \\
\text { after } 8 \text { hours }(p=0.002) \\
\text { otherwise N/S }\end{array}$ & \\
\hline & & & Length of ICU stay & $\begin{array}{l}\text { Shorter ICU stay: } 11.6 \mathrm{v} \\
8.0 \text { days }(p=0.04)\end{array}$ & $\begin{array}{l}\text { Increase in ICP treated by } \\
\text { stepwise increase therapy, } \\
\text { thus not surprising that no } \\
\text { difference in ICP seen }\end{array}$ \\
\hline & & & Complications & $\begin{array}{l}\text { Higher incidence in RL } \\
\text { group (N/S) }\end{array}$ & \\
\hline & & & Ventilation times & $\begin{array}{l}\text { Longer duration in RL } \\
\text { group (N/S) }\end{array}$ & \\
\hline & & & $\begin{array}{l}\text { Length of hospital stay } \\
\text { Survival }\end{array}$ & $\begin{array}{l}\text { No significant difference } \\
\text { No significant difference }\end{array}$ & \\
\hline
\end{tabular}

Sahay JN, Bell R, Chatteriee SS, et al. Comparative study of effects of intravenous administration of aminophylline, salbutamol and terbutaline in patients suffering from reversible airways obstruction. Curr Med Res Opin 1984;9:1-6. Sharma TN, Gupta RB, Gupta PR, et al. Comparison of intravenous aminophylline, salbutamol and terbtaline in acute asthma. Indian J Chest Dis Allied Sci 1984:26:155-8.

Grief J, Markovitz L, Topilsky $M$, et al. Comparison of intravenous salbutamol (albuterol) and aminophylline in the treatment of acute asthmatic attacks. Ann Allergy 1985;55:504-6.

\section{Hypertonic or isotonic saline in hypotensive patients with severe head injury}

\section{Report by Rupert Jackson, Consultant Checked by John Butler, Consultant}

\section{Abstract}

A short cut review was carried out to establish whether hypertonic or isotonic saline improved the outcome most in patients with severe head injury. Altogether 66 papers were found using the reported search, of which three presented the best evidence to answer the clinical question. The author, date and country of publication, patient group studied, study type, relevant outcomes, results and study weaknesses of these best papers are tabulated. A clinical bottom line is stated.

\section{Clinical scenario}

You are resuscitating a 30 year old man with a severe closed head injury. His GCS was 3 on admission. He is intubated and ventilated and a CT scan is being organised. His blood pressure is only $90 / 40 \mathrm{~mm} \mathrm{Hg}$. You want to improve cerebral perfusion by giving intravenous fluid but are aware that too much fluid might worsen cerebral oedema. You wonder whether there would be any advantage in giving hypertonic saline.

\section{Three part question}

In [patients with severe head injury and low blood pressure] is [hypertonic saline better than isotonic fluids] at [increasing 
cerebral perfusion, reducing intracranial pressure and improving outcome]?

\section{Search strategy}

Medline 1966-10/03 using the OVID interface. [exp hypertonic solutions/or exp saline solution, hypertonic/or "hypertonic saline".mp.] AND [exp craniocerebral trauma/OR "head injury".mp. OR "HEAD INJURIES".mp. OR exp head injuries, closed/OR "head injured".mp. OR exp brain injuries/ OR "brain injury".mp.]

\section{Search outcome}

Altogether 66 papers were found of which three were trials of sufficient quality that addressed the three part question. These are displayed in table 6.

\section{Comment(s)}

All three trials showed some improvements in patients with head injury treated with hypertonic saline compared with standard care. The largest showed a two times survival advantage in those treated with hypertonic saline but this was a cohort analysis rather than a PRCT. It is not established how much hypertonic saline should be given and when. A large randomised controlled trial would help to establish the role of hypertonic saline.

\section{- CLINICAL BOTTOM LINE}

There is insufficient evidence at present to justify the use of hypertonic saline as resuscitation fluid in patients with severe head injury.

Wade CE, Grady JJ, Kramer GC, et al. Individual patient cohort analysis of the efficacy of hypertonic saline/dextran in patients with traumatic brain injury and hypotension. J Trauma 1997:42(suppl 5):61-5.

Shackford SR, Bourguignon PR, Wald SL, et al. Hypertonic saline resuscitation of patients with head injury: a prospective, randomized clinical trial. I Trauma 1998;44:50-8.

Simma B, Burger R, Falk $M$, et al. A prospective, randomized and controlled study of fluid management in children with severe head injury: lactated Ringer's solution versus hypertonic saline. Crit Care Med 1998;26:1265-70. 